\title{
The Energy Performance Contracts to enhance the energy efficiency in public sector. The case of Piemonte Region
}

\author{
Silvio De Nigris ${ }^{1, *}$ \\ ${ }^{1}$ Piemonte Region, Direzione Competitività del Sistema Regionale, Settore Sviluppo Energetico Sostenibile, Torino, Italy
}

\begin{abstract}
Energy performance contracts (EPC) are able to tackle most of the existing barriers for the upscaling of energy efficiency investments in the public sector. Since EPC are complex, a project development assistance service (PDA) supporting small and medium municipalities is essential for their successful implementation. This PDA should be designed following the one-stop shop approach and should provide assistance and solutions along the entire investment chain (from the decision making process, to the monitoring of performance). The case studies of Piemonte Region implemented in the context of EU funded projects demonstrate that this approach is effective and successful. Nevertheless, further actions could ease the wider use of such an approach, such as the specific modification of the legislative framework, the standardisation of tender documents and procedures, tools for de-risking the financial support of EPC and the institutionalisation of the PDA approach among regional authorities and other territorial coordinators.
\end{abstract}

\section{Introduction to Energy Performance Contracts}

During the session "the technological way and good practices" of Science for Future's conference, one pillar was dedicated to the Energy topic. Technological innovation is essential, but financial and contractual innovation is also required to enhance energy efficiency. One of the most promising innovation of such is offered by Energy Performance Contracts and the best practices implemented by Piemonte Region were presented as an example.

According to EU Directive 2012/27 on energy efficiency, an Energy Performance Contract (EPC) is a contractual arrangement between the beneficiary and the provider of energy efficiency improvement measures, verified and monitored during the whole contract, where investments in that measure are paid for in relation to a contractually agreed level of energy efficiency improvement or other agreed energy performance criterion, such as financial savings.

The EPC, thus, must guarantee the achievement of an amount of energy efficiency, which must be measured and verified through the contract duration. The payment of such a contract is based on a fee that is bound to the level of performance reached every year. To do so, an EPC must list all the measures and investments that need to be implemented in order to achieve the guaranteed performance and an overview of the financial conditions of the investment plan. The EPC is an innovative approach for the implementation of investments in energy efficiency, mostly for the public sector, because it is not based on the purchase of works, but on the purchase of a guaranteed level of energy efficiency. The investments are decided by the company who is committing itself to reach the guaranteed performance. Generally speaking, the contractor is an energy services company (ESCO) and the investment is usually implemented through a third party financing scheme. In this way the financial risk is transferred to the ESCO (the private party of the contract) and the public authority commits to paying a fee for the duration of the contract, which should be long enough to provide sustainability for the investment itself. Since the return on the ESCO is closely connected to the achievement of the performance, it is in the interest of the ESCO to implement it in an effective way and to manage the renovated assets in the best way for duration of the contract.

Public authorities have started looking at EPCs favourably, mainly because they are seen as a way to implement investments even in the presence of financial constraints and budget shortages. This approach requires close attention to the way the contract is drafted, in order to follow the EUROSTAT rules and be sure to record the EPC investment correctly in the balance sheet. On May 2018 a very clear EPC guide [1] was issued by the European Investment Bank in order to establish which party to the EPC is the economic owner of the measures comprising capital expenditure (e.g., construction works, equipment) that are implemented under the EPC (the EPC assets). Generally speaking, the economic owner is the party that bears most of the risks and has the right to most of the rewards associated with those assets. If the assessment of risks and rewards indicates that government is the economic owner of the EPC assets, then the EPC must be recorded on the balance sheet for government.

Corresponding author: silvio.denigris $@$ regione.piemonte.it 


\section{The policy framework}

The International Paris Climate Agreement recognises energy efficiency as one the most cost-effective ways to support the transition to a low-carbon economy and the Energy Union Framework Strategy is strongly focused on energy efficiency.

A large share of the target fixed for energy efficiency $(-32,5 \%$ at EU level and $-40 \%$ at the national level of primary energy compared to the trends recorded in the reference scenario, PRIMES 2007) is to be achieved in the building sector. According to the recent proposal of the National Plan for Energy and Climate, this would mean 3.3 Mtoe less primary energy for Italy [2]. There is the need to accelerate the rate of renovation in European buildings, which stands at about $1 \%$ per year. This can be done either with a change in the role of the financial sector or an increasing role for IT and smart technology $[3,4]$.

At a national level it is estimated that around €8 billion euro per year are needed in order to achieve the 2030 energy efficiency goals, so that an additional $€ 110$ billion investment on a cumulative basis would be mobilised. So far, Italy has provided about $€ 4$ billion of public funds per year, which is already a huge amount, but this contribution needs to double and private financing will have to be unlocked at scale [3,4].

EPC with third party financing is, thus, an option which offers the opportunity to trigger investments in energy efficiency for public sector attracting private funding. Energy policy should thus create more favourable investment conditions, encourage demand for energy efficiency and help end users to undertake related investments more easily.

\section{Barriers for public sector and possible solutions}

Thanks to the EU Smart Financing for Smart Buildings initiative [5], several projects have been supported by the EU Commission under the ELENA Program, the Energy Efficiency Fund, Horizon and Interreg Programs. The Piemonte Region is managing some projects, providing technical assistance to municipalities for promoting the use of EPC. At the basis of such projects, there is the will to address the main barriers and constraints that prevent the public sector from implementing energy efficiency investments. The main barriers are:

- lack of technical knowledge and lack of money to recruit external expertise;

- lack of time to keep existing or potential skills updated, due to the fact that the staff must deal with a wide range of topics and issues and cannot develop specific competences in energy efficiency;

- difficulties keeping the pace of innovation in energy efficiency and be able to be on the market at the right time;

- difficulties in assessing investment proposals delivered by the private sector (ESCOs, utilities, etc.), so that the public interest or a well-balanced interest between public and private is pursued;
- a scale factor which prevents municipalities launching investment plans which are in the interest of the market. The dimension of investments is usually too small and not profitable enough to attract private investors;

- poor communication skills, so that good practices are not promoted and disseminated in the right way.

Most of the above constraints can be tackled with two main actions. The first is the one-stop-shop approach, and the second one is the aggregation of demand. Of course, both benefit from each other.

A recent EU publication [6] provides an overview of existing one-stop-shop approaches, defining them as services that usually cover the whole or a large part of the customer chain from information, technical assistance, structuring and provision of financial support, to the monitoring of savings. These facilities should lead to more locally-developed project pipelines and strong and trustworthy partnerships with local actors (e.g., SMEs, financial institutions, and energy agencies), the key being to connect the supply of finance with the demand for it.

Aggregation of the demand is essential in order to reach the required scale factor to generate economies in terms of investments and transaction costs.

\section{Case studies in Piemonte Region}

This first case study took place in Piemonte, implementing the 2020TOGETHER project. It aimed to start a coordinated action involving regional, provincial and local authorities, financial institutions and local industries/investors, and to launch an investment programme based on EPC and third party investment (TPI). The project provided the investment of 12.5 million of euro for the energy renovation of public buildings and street lights [7]. Thanks to EU cofinancing, a project development assistance (PDA) service was set up, in collaboration with Environment Park and the Metropolitan City of Torino, and was offered to a number of municipalities. The project implemented a large investment program for the replacement of heating boilers in 118 public buildings owned by the City of Torino for an investment of 7.5 million of euro. Two investment programs based on the bundling approach were also implemented:

- one for 18 public buildings owned by five different municipalities with a 13 year EPC duration;

- another for about 3000 public street light points, owned by six municipalities with 13 year EPC duration.

Both of the above investment plans were the most innovative part of the project and have been successful.

The bundling of buildings guaranteed average energy savings of about $61 \%$ and an economic saving for the municipalities of about $12 \%$ on average (in comparison with baseline energy bills and costs). The investment was about 2.5 million of euro (VAT excluded) with a net present value of about $540 \mathrm{k} €$ and an internal interest rate of about $7 \%$. 
Bundling for the street lights guaranteed average energy savings of about $68 \%$ and economic savings for the municipalities of about $11,5 \%$ on average (in comparison to baseline energy bills costs). The total investment is expected to be about 2.4 million of euro (VAT excluded) with a net present value of about 400 thousands of euro and an internal interest rate of about $10 \%$.

A similar approach has been implemented in several other projects across europe. Most of those projects have been implemented thanks to the support of Elena Program [8] managed by the European Investment Bank or the Aggregation - Project Development Assistance measure in the framework of Horizon 2020 Program [9]. Such kind of projects [10-11] have dealt with the public sector [12-17], social housing [18-19] and private buildings [20-23], exploiting different implementation schemes of a similar approach.

\section{The project development assistance approach}

The PDA, in line with the one-stop-shop approach, provided a set of services for both the above bundling investments, including:

- coordination and support action (aggregation of the demand, information and definition of the agreements between the involved municipalities);

- technical assistance in the development of the investment plan (energy audits and financial and economic assessment, definition of energy and economic baselines);

- legal assistance in launching the tender procedure (drafting of tender documents, assistance in signing contracts, etc.);

- communication support (press releases drafting, organisation of site visits, conferences, production of brochures, etc.).

The idea behind the PDA is that every single step of the process is essential and the absence of any one could hinder the success of the whole process itself. This is the reason why a PDA with a one-stop-shop approach must be comprehensive.

The main outcome of the coordination and support action was the signature of an agreement between municipalities and the contracting authority (in this case the Metropolitan City of Torino) that was in charge of managing the tender procedure and awarding the ESCO.

At the end of the experience it was possible to make the following remarks about the bundling approach:

1. If the agreement is between the municipality and the contracting authority, the municipalities are not all bound together. This is very important in order to give flexibility to the process. Since tender preparation requires quite a lot of time, it is important that the overall process is not jeopardised by the resignation of any actor.

2. The agreement should fix the deadlines, obligations and contractual liabilities of the parties

3. The contracting authority must be able to influence the municipalities (political power) and/or the other way around, so that there is a common interest. As soon as a bundling project starts its preparation, it is likely that ESCOs will approach municipalities for a one-to-one engagement for alternative approaches.

4. The bundled sample of buildings must be interesting for ESCOs in terms of the amount of investments and returns. This means that attention must be paid to technical and administrative constraints (investments already implemented, architectural constraints, and management contracts in place).

5. Given that the best buildings are those with low performance and high consumption, "low-hanging fruits" can be bundled together with less profitable ones, bearing in mind that the bundling itself must be interesting for ESCOs.

As far as the technical assistance service is concerned, the methodology is based on modular steps, as follows: the selection of the assets, the energy audit, economic and financial simulation, and selection of the baseline scenario.

The selection of the assets is made in such a way that the following conditions are respected:

- An absence of constraints that could hinder the implementation of energy renovation (i.e for building: architectural, seismic, etc.);

- absence of important interventions in recent years or planned in the coming months/years;

- the public administration is not only the owner of the asset, but it is also paying its energy bills;

- the asset has important energy consumption.

For the latter criteria the following general conditions are considered and applied with a certain degree of flexibility.

Tab 1. Conditions for the selection of the buildings

\begin{tabular}{|l|c|}
\hline Condition & Threshold \\
\hline Net Surface & $>1.000 \mathrm{mq}$ \\
\hline Heated Volume & $>4.000 \mathrm{mc}$ \\
\hline Natural gas consumption & $>30.000 \mathrm{Smc}$ \\
\hline Energy bill for heating & $>20.000 €$ \\
\hline
\end{tabular}

Energy audits were carried out using the European Standard EN 16247:2014. Based on its results, the EPC conditions are defined in order to make the contract attractive for ESCOs, keeping a fair balance between private and public interest. During this phase, and after an economic and financial simulation of the feasible investments, different scenarios with different numbers are presented to the public authority (owner of the asset) in order to select the best option. Possible scenarios can define a longer duration with consequently greater value of both investments and savings (either way energy and economic), or a shorter duration with a lower value of investments and consequently of energy and economic savings [24]. 
Finally the public authorities, with the support of the PDA structure, decide on the following data included as the baseline in the tendering documents:

- length of the contract (the payback time of energy savings measures should be lower than contract duration);

- $\quad$ minimum energy savings required;

- minimum cost saving required;

- minimum investment value required.

The above data was used to fix the baselines for the tendering procedure. The bidders were asked to submit a proposal that would simultaneously increase the minimum energy savings percentage, the investment value and the cost savings. In consequence, the municipalities receive an energy refurbishment of the assets, with investments implemented and economic savings on the current expenditures. The fixed condition is the contract duration, which is relatively long (13 years in this case) in comparison to normal standards. The durability of the investments was a major evaluation criteria. The aim was to give preference to those investments with a lifespan longer than the contract duration (i.e. for buildings, the insulation of the envelope or changes to windows was weighted more than a change to the boiler or installation of thermostatic valves). The outcome for the investment plan of the 18 buildings has been very promising, as one building was NZEB certified and 13 received a full or partial insulation of the envelope [7]. Works were concluded during 2018.

The legal assistance service provides the drafting of tender documents and the decision of the tender procedure that the contracting authority follows.

The tenders documents include $[25,26]$ :

- tender specification, with rules and procedures to manage the procurement phase;

- management and technical specifications. The document highlights the key issues and aspects that deal with the management phase. It is a crucial document, as the EPC contract lasts for several years;

- Monitoring and Verification Plan. This is a plan that sets the rules and procedures for checking the level of performance on which the operational payments are based;

- EPC contract scheme. This defines duties, liabilities, rights and obligations regarding the ESCO awarded and the public administration. It also clarifies the risk allocation among the involved parties.

The Monitoring and Verification Plan is very peculiar to the list above. The guaranteed savings are set in the contract and the ESCO guarantees the annual volume of energy savings in physical units (such as $\mathrm{MWh}$ ). If the savings are smaller than the guaranteed volume of savings, the corresponding amount will be fully reimbursed by the ESCO to the public administration (P.A.) according to the contract. If the savings are higher than the guaranteed volume, excess savings are to be divided between ESCO and the P.A. according to the methodology defined in the contract. Eurostat clearly states that it is not possible to give less than two-thirds of the extra savings to the ESCO [1]. The transparency of the savings achieved depends on the quality of measurement and verification $(\mathrm{M} \& \mathrm{~V})$ provided. In general the more independent the $\mathrm{M} \& \mathrm{~V}$ on the ESCO, the more transparent are he energy savings.

\section{Follow up activities in Piemonte Region}

After the experience enabled by the region in the 2020Together project, at least two other projects were implemented, following a similar approach: PEACE_Alps [27] and STEPPING [28]. An additional 40 buildings and 10,000 street light points have been assessed and prepared for renovation in these projects, with EPC and third party financing in different investment packages.

\section{Conclusions}

Given that energy efficiency is a must in the policy framework and the building sector is where most of the investments must be triggered in a decade, different options are nowadays available. EPC is one of the most promising, because it is based on performance (i.e. real savings) and not on construction works. It focuses on the goals rather than on the means to reach them. It is well known that sometimes the expected savings are not achieved, for a number of possible reasons. The EPC introduces a system and procedures, based on monitoring and verification, that substantiate the real achievement of the performance with a series of extra gains or losses.

The potential upscale of the EPC is now mainly based on the realisation of the following conditions, that would reduce the market risks and reduce transaction costs, which are still quite high, for either public authorities and for ESCOs.

1. There is a need to exploit the added value of standardisation. Standard EPC contracts would avoid much bureaucracy and provide confidence about such contracts among the public staff. Although certain parts of the EPC contract can be standardised, there is still a need to leave a certain degree of flexibility in order to best customise each project $[3,4]$.

2. There is still the need for more transparency in the Italian Code of public contracts. Starting from existing successful practice, clarifications need to be introduced by law (i.e. the provisions on the level of design for EPC) $[3,4]$.

3. It is useful to have guarantee funds or other financial tools at the national level, in order to increase the confidence of the financial sector in such contracts.

4. Finally, the one-stop-approach is to be replicated, as it is proven to be effective. It is important that such an approach would be part of the mission of regional public authorities and not only related to stand alone projects which need to be funded by the EU or other bodies. This approach is clearly promoted by the Smart Financing for Smart Buildings Initiative and advocated by Directive 2018/844/EU. 


\section{References}

1. European Investment Bank, A guide to the statistical treatment of energy performance contracts (2018) [Online]. Available: https://www.eib.org/attachments/pj/guide_to_statisti cal_treatment_of_epcs_en.pdf [Access date: $26^{\text {th }}$ February 2019].

2. MISE, MAAT, MIT, Proposta di Piano Nazionale integrato per l'Energia e il Clima (2018) [Online]. Available:

https://www.mise.gov.it/images/stories/documenti/P roposta_di_Piano_Nazionale_Integrato_per_Energia e_il_Clima_Italiano.pdf [Access date: $26^{\text {th }}$ February 2019].

3. EASME, Financing Energy Renovation of buildings in Italy, Croatia and Slovenia, Meeting proceedings (2017) [Online]. Available: https://ec.europa.eu/energy/en/topics/energyefficiency/financing-energy-efficiency/sustainableenergy-investment-forums/financing-energyefficiency-italy-croatia-and-slovenia [Access date: $26^{\text {th }}$ February 2019].

4. EASME, National roundtable on financing energy renovation of buildings in Italy, Meeting proceedings (2018) [Online]. Available: https://ec.europa.eu/energy/en/topics/energyefficiency/financing-energy-efficiency/sustainableenergy-investment-forums/roundtable-financeenergy-efficiency-italy-24-may-2018-rome-italy [Access date: $26^{\text {th }}$ February 2019].

5. EU Commission, ANNEX Accelerating clean energy in buildings - Clean Energy For Al Euroeans (2016) [Online]. Available: https://ec.europa.eu/energy/sites/ener/files/document s/1_en_annexe_autre_acte_part1_v9.pdf [Access date: $3^{\text {rd }}$ March 2019].

6. B. Boza-Kiss Benigna, P. Bertoldi, One-stop-shops for energy renovations of buildings, European Commission, Ispra (2018).

7. Metropolitan City of Torino, Regione Piemonte, Environment Park, I contratti EPC per la Pubblica Amministrazione - 2020TOGETHER: il modello e $i$ risultati (2017) [Online]. Available: http://www.cittametropolitana.torino.it/cms/risorse/a mbiente/dwd/ris-

energetiche/progetti/2020together/attivit\%C3\%A0 progetto/2020together_final_publication_15_feb_20 17_IT_DEF.pdf [Access date: $3^{\text {rd }}$ March 2019].

8. European Investment Bank, ELENA - supporting investments in energy efficiency and sustainable transport (2019) [Online]. Available: https://www.eib.org/en/products/advising/elena/inde x.htm [Access date: $3^{\text {rd }}$ March 2019].

9. EASME, Horizon 2020, Work Programme 20182020 - 10. Secure, clean and efficient energy (2018) [Online]. Available: http://ec.europa.eu/research/participants/data/ref/h20 20/wp/2018-2020/main/h2020-wp1820energy_en.pdf [Access date: $3^{\text {rd }}$ March 2019].
10. European Investment Bank, ELENA - Closed Project Factsheets (2019) [Online]. Available: https://www.eib.org/en/products/advising/elena/com pleted-projects/index.htm [Access date: $3^{\text {rd }}$ March 2019].

11. EASME, List of PDA projects (2019) [Online]. Available: https://bit.ly/2WtUs22 [Access date: $3^{\text {rd }}$ March 2019].

12. PRODESA project [Online]. Available: https://cordis.europa.eu/project/rcn/209996/factsheet len [Access date: $3^{\text {rd }}$ March 2019].

13. BeenerGi project [Online]. Available: https://cordis.europa.eu/project/rcn/194620/factsheet len [Access date: $3^{\text {rd }}$ March 2019].

14. Accelerate SUNShINE project [Online]. Available: https://cordis.europa.eu/project/rcn/209848/factsheet len [Access date: $3^{\text {rd }}$ March 2019].

15. FESTA project [Online]. Available: https://cordis.europa.eu/project/rcn/194636/factsheet len [Access date: $3^{\text {rd }}$ March 2019].

16. BUNDLE UP project [Online]. Available: hhttps://cordis.europa.eu/project/rcn/214802/factshe et/en [Access date: $3^{\text {rd }}$ March 2019].

17. Rodoshop project [Online]. Available: https://cordis.europa.eu/project/rcn/210315/factsheet len [Access date: $3^{\text {rd }}$ March 2019].

18. ENERSHIFT project [Online]. Available: https://cordis.europa.eu/project/rcn/200094/factsheet len [Access date: $3^{\text {rd }}$ March 2019].

19. Lemon project [Online]. Available: https://cordis.europa.eu/project/rcn/200000/factsheet len [Access date: $3^{\text {rd }}$ March 2019].

20. SUNShINE project [Online]. Available: https://cordis.europa.eu/project/rcn/194599/factsheet len [Access date: $3^{\text {rd }}$ March 2019].

21. HousEEnvest project [Online]. Available: https://cordis.europa.eu/project/rcn/213567/factsheet len [Access date: $3^{\text {rd }}$ March 2019].

22. EasyCOPRO project [Online]. Available: https://cordis.europa.eu/project/rcn/213572/factsheet len [Access date: $3^{\text {rd }}$ March 2019].

23. HAPPI project [Online]. Available: https://cordis.europa.eu/project/rcn/213582/factsheet len [Access date: $3^{\text {rd }}$ March 2019].

24. Environment Park, EPC Investment Plans for public buildings (2018) [Online]. Available: https://stepping.interreg-med.eu/deliverable-library/ [Access date: $3^{\text {rd }}$ March 2019].

25. Metropolitan City of Torino, Regione Piemonte, Environment Park, Guida per la redazione di contratti EPC - Esperienza 2020 Together (2017) [Online]. Available: http://www.cittametropolitana.torino.it/cms/risorse/a $\underline{\text { mbiente/dwd/ris- }}$ energetiche/progetti/2020together/attivit\%C3\%A0 progetto/2020Together_D4.3_Revised_EPC_schem e_PU.pdf [Access date: $3^{\text {rd }}$ March 2019]. 
26. Regione Piemonte, Tenders models, specifications and contract schemes for EPC procurement (2018) [Online]. Available: https://stepping.interregmed.eu/deliverable-library/ [Access date: $3^{\text {rd }}$ March 2019].

27. Regione Piemonte, Peace_Alps project [Online]. Available: https://www.alpinespace.eu/projects/peace_alps/en/home [Access date: $3^{\text {rd }}$ March 2019].

28. STEPPING project [Online]. Available: https://stepping.interreg-med.eu [Access date: $3^{\text {rd }}$ March 2019]. 